Jurnal Teknologi, 51(F) Dis. 2009: 17-27

(C) Universiti Teknologi Malaysia

\title{
THE SENSITIVITY ANALYSIS ON GROUNDWATER FLOW AND SOLUTE TRANSPORT OF SUTRA 2D3D.1
}

\author{
SUNNY GOH ENG GIAP ${ }^{1}$
}

\begin{abstract}
Arsenic groundwater pollution in Bangladesh has been known as possibly the largest mass poisoning of human population in history. Based on drinking water quality of $50 \mu \mathrm{g} \mathrm{As} / \mathrm{L}, 25$ million people in Bangladesh are affected. If the range from 10-50 $\mu \mathrm{g} \mathrm{As} / \mathrm{L}$, with $10 \mu \mathrm{g} \mathrm{As} / \mathrm{L}$ is used as World Health Organization (WHO) current standard, another 25 million people will be affected. The latest research findings have demonstrated that the availability of organic matter in the presence of indigenous bacteria in aquifer critically implicated in the release of arsenic from sediments. A number of software is available for conducting modelling on solute transport of dissolved organic carbon from surface to subsurface. In this study, SUTRA 2D3D.1 has selected to model at Manikganj district in Bangladesh. This study focussed on sensitivity analysis as a primary concern, before any further modelling effort. The results of simulation found that the input parameters can be divided into those with either positive or negative linear relation with the time taken for surface-derived solutes to be transported to typical depths of groundwater abstraction. The completion of sensitivity analysis has created an opportunity of further development in developing minimum and maximum scenarios by considering the shallow and deep tubewells abstraction.
\end{abstract}

Keywords: Sensitivity analysis; solute transport; arsenic; groundwater; Bangladesh

\begin{abstract}
Abstrak. Pencemaran arsenik di dalam air bawah tanah di Bangladesh telah dikenali sebagai keracunan populasi manusia yang mungkin terbesar dalam sejarah. Berdasarkan kualiti air minum $50 \mu \mathrm{g}$ As/L, keracunan melibatkan seramai 25 juta rakyat Bangladesh. Jika julat di antara 10-50 $\mu \mathrm{g}$ As/L, dengan $10 \mu \mathrm{g}$ As/L digunakan sebagai standard Pertubuhan Kesihatan Sedunia, seramai 25 juta rakyat Bangladesh lagi akan keracunan. Penemuan penyelidikan terbaru menunjukkan bahawa kewujudan bahan organik dengan kehadiran bakteria asal di dalam tanah dengan kritikalnya dikaitkan dengan pembebasan arsenik dari sedimen tanah. Beberapa perisian sedia ada yang boleh digunakan untuk melakukan permodelan pengangkutan karbon organik terlarut dari permukaan bumi ke dalam air bawah tanah. Dalam kajian ini, SUTRA 2D3D.1 telah dipilih untuk melakukan permodelan di daerah Manikganj, Bangladesh. Tumpuan kajian ini difokuskan pada darjah sensitif analisis sebagai tumpuan utama, sebelum melanjutkan sebarang usaha permodelan yang seterusnya. Keputusan simulasi mendapati bahawa parameter input boleh dibahagikan kepada sama ada hubungan linear positif ataupun negatif bagi masa yang diambil untuk bahan terlarut hasilan permukaan untuk diangkut bersama dengan air ke dalam tanah kebiasaan kedalaman telaga. Penyelesaian darjah sensitif analisis telah mewujudkan peluang untuk pembangunan model yang seterusnya untuk membangunkan senario minimum dan maksimum dengan mengambil kira penyedutan air dari telaga cetek dan yang mendalam.
\end{abstract}

Kata kunci: Darjah sensitif analisis; pergerakan bahan terlarut; arsenik; air bawah tanah; Bangladesh

1 Department of Engineering Science, Faculty of Science and Technology, Universiti Malaysia Terengganu, Mengabang Telipot, 21030 Kuala Terengganu, Malaysia

Tel: +609-6683622, Fax: +609-6696440. Email: sunnyg@umt.edu.my 


\subsection{INTRODUCTION}

Arsenic groundwater pollution in Bangladesh is a long well known problem, particularly in southern and eastern parts of the country. The source of arsenic is well agreed from geological source. A number of different hypotheses supporting the mobilization of arsenic, but the most reasonable hypothesis is from the hypothesis of oxyhydroxide reduction by microbiological process [1]. The availability of organic carbon could play a key role in governing microbial community activity that causes the release of arsenic [2]. Harvey and his co-workers suggested that massive groundwater abstraction in Bangladesh may result in the influx of surface derived organic carbon into these aquifers, thereby accelerating the release of arsenic and exacerbating the hazard [3].

A research effort has been carried out by Klump and his co-workers to model the flow of groundwater based on three different scenarios for a small village of Bejgaon, near the village of Sreenagar in the rural Munshiganj district of Bangladesh [4]. In addition, there are many other places in east Bengal are available for study along with different geological properties, rainfall profiles and groundwater recharge, irrigation methods and groundwater abstraction.

A great number of software available for modelling groundwater flow and solute transport of dissolved organic carbon, such as, HYDRUS 2D, HYDRUS 3D, MT3DMS, MODFLOW 2000, RT3D, SUTRA 2D3D.1, SUTRA-MS and others. The expectation criteria on groundwater modelling software are as follow: minimum expenses with acceptable modelling results; saturated and unsaturated groundwater modelling; only single solute transport require; capable of two-dimensional modelling; could be extended for three-dimensional, for later development; capable of transient flow and transport; capable of modelling different layers of subsurface properties; capable of changing flow boundary condition; least time consuming in converting the output file into contour visualization software; easy input of data; and allow access to source code [5]. All these have at least proven SUTRA 2D3D.1 as a suitable selection in carrying out modelling effort on solute transport of dissolved organic carbon on groundwater flow. However, based on current publication, this software has not been subjected to sensitivity analysis, which can be used to assess the robustness of the results in respect of uncertain decisions or assumptions about the data.

Therefore, the aim of this research work is to carry out the sensitivity analysis on SUTRA 2D3D.1 based on groundwater flow and solute transport of dissolved organic carbon from agricultural area to lower shallow and deep aquifers. In responding to the reality that hydrologic systems may not be well defined, hence, SUTRA 2D3D.1 is a useful tool for hypothesis testing and for helping to understand system physics, when certainty approach is often inappropriate.

\subsection{GOVERNING EQUATIONS}

SUTRA is a computer program that capable of simulating fluid movement and transport of a dissolved substance in subsurface. There are two main equations that responsible 
for two interdependent processes in the simulation: fluid density-dependent saturated and unsaturated groundwater flow (conservation of mass of fluid); and transport of a solute in groundwater and solid matrix of the aquifer (conservation of mass of solute). These are summarized below [6].

\subsection{The Conservation of Mass of Fluid}

The equation that responsible for the process of fluid density-dependent saturated and unsaturated groundwater flow is represented by the following expression:

$$
\left(S_{w} \frac{\partial(\phi \rho)}{\partial \rho}+\phi \rho \frac{\partial S_{w}}{\partial \rho}\right) \frac{\partial p}{\partial t}+\left(\phi S_{w} \frac{\partial \rho}{\partial C}\right) \frac{\partial C}{\partial t}-\underline{\nabla} \cdot\left[\left(\frac{\underline{\underline{k}} k_{r} \rho}{\mu}\right) \cdot(\underline{\nabla} \rho-\rho \underline{g})\right]=Q_{p}
$$

where $\phi$, porosity (dimensionless); $S_{w}$, saturation (dimensionless); $\rho$, fluid density $\left(\mathrm{kg} / \mathrm{m}^{3}\right) ; p$, pressure $\left(\mathrm{kg} / \mathrm{m} / \mathrm{s}^{2}\right) ; C$, solute concentration (kg solute $\left./ \mathrm{kg}\right) ; \underline{k}$, solid matrix permeability $\left(\mathrm{m}^{2}\right) ; k_{r}$, relative permeability to fluid flow (dimensionless); $\underline{g}$, gravitational acceleration $\left(\mathrm{m} / \mathrm{s}^{2}\right)$; and $\mu$, fluid viscosity $(\mathrm{kg} / \mathrm{m} / \mathrm{s})$; and $Q_{p}$, external fluid source $(\mathrm{kg} /$ $\left.\mathrm{m}^{3} / \mathrm{s}\right)$.

\subsection{The Conservation of Mass of Solute}

The following equation is representing the solute transport in groundwater and solid matrix of the aquifer:

$$
\begin{aligned}
{\left[\phi S_{w} \rho\right.} & \left.+(1-\phi) \rho_{s} \kappa_{1}\right] \frac{\partial C}{\partial t}+\phi S_{w} \rho \underline{v} \cdot \underline{\nabla} C-\underline{\nabla} \cdot\left\{\rho\left[\phi S_{w}\left(D_{m} \underline{\underline{I}}+\underline{\underline{D}}\right)\right] \cdot \underline{\nabla} C\right\} \\
& =Q_{p}\left(C^{*}-C\right)+\phi S_{w} \rho \gamma_{1}^{w} C+(1-\phi) \rho_{s} \gamma_{1}^{s} C_{s}+\phi S_{w} \rho \gamma_{o}^{w}+(1-\phi) \rho_{s} \gamma_{o}^{s}
\end{aligned}
$$

where $C_{s}$, specific concentration of adsorbate on solid grains ( $\mathrm{kg}$ solute/kg solid matrix); $\rho_{s}$, solid grains density in solid matrix $\left(\mathrm{kg}\right.$ solid matrix $\left./ \mathrm{m}^{3}\right) ; D_{m}$, apparent solute molecular diffusivity in solution in a porous medium $\left(\mathrm{m}^{2} / \mathrm{s}\right) ; \underline{I}$, identity tensor (dimensionless); $\underline{\underline{D}}$, dispersion tensor $\left(\mathrm{m}^{2} / \mathrm{s}\right) ; C^{*}$, solute concentration of fluid sources (kg solute/kg); $\gamma_{1}^{w}$, first order mass production or decay rate of solute $\left(\mathrm{s}^{-1}\right) ; \gamma_{0}^{w}$, zeroorder solute mass production or decay rate $(\mathrm{kg}$ solute $/ \mathrm{kg} / \mathrm{s}) ; \gamma_{1}^{s}$, first-order mass production or decay rate of adsorbate $\left(\mathrm{s}^{-1}\right) ; \gamma_{o}^{s}$, zero-order adsorbate mass production or decay rate $(\mathrm{kg}$ solute $/ \mathrm{kg}$ solid matrix $/ \mathrm{s}) ; \kappa_{1}$, first general sorption coefficient $(\mathrm{kg} / \mathrm{kg}$ solid matrix); and $\underline{v}$, average fluid velocity $(\mathrm{m} / \mathrm{s})$.

\subsection{METHODOLOGY}

\subsection{Computer and Software}

In completing the above-mentioned tasks, a number of software were used, they were Microsoft Word 2003, Microsoft Excel 2003, SUTRA Suite (only simulation code: 
SUTRA Version 2D3D.1, and post-processor: ModelViewer), Digital ${ }^{\mathrm{TM}}$ Visual Fortran Standard Edition Version 5.0A, Notepad, Mathematica 5.0 and Paint. The whole simulation was conducted by using Intel Centrino ${ }^{\mathrm{TM}}$ Processor $1.50 \mathrm{GHz}, \mathrm{RAM} 1.50$ GB and an allowable 12 GB of hard drive size for storage.

\subsection{Selected Site and Initial Input Parameters Values for SUTRA}

Manikganj district lithology was selected for the current hypothetical investigation. It has a less complicated lithology, which had reduced significantly time required in assigning the permeability values for elementwise data for SUTRA.

The investigation of the site was carried out by setting up an initial simplest form of 2D vertical slide model and then, gradually increasing its complexity by considering other parameters. The slide model has $310 \mathrm{~m}$ height, $2000 \mathrm{~m}$ length and $1 \mathrm{~m}$ thickness. A $10 \mathrm{~m}$ vertical height over $20 \mathrm{~m}$ horizontal length element was set, which generated 32 and 101 nodes, respectively. This is illustrated in Figure 1.

The initial input parameters values for the simplest form of $2 \mathrm{D}$ vertical slide model were basically divided into three categories: parameters with average values; parameters with the lowest values; and parameters not consider in the initial simple modelling work.

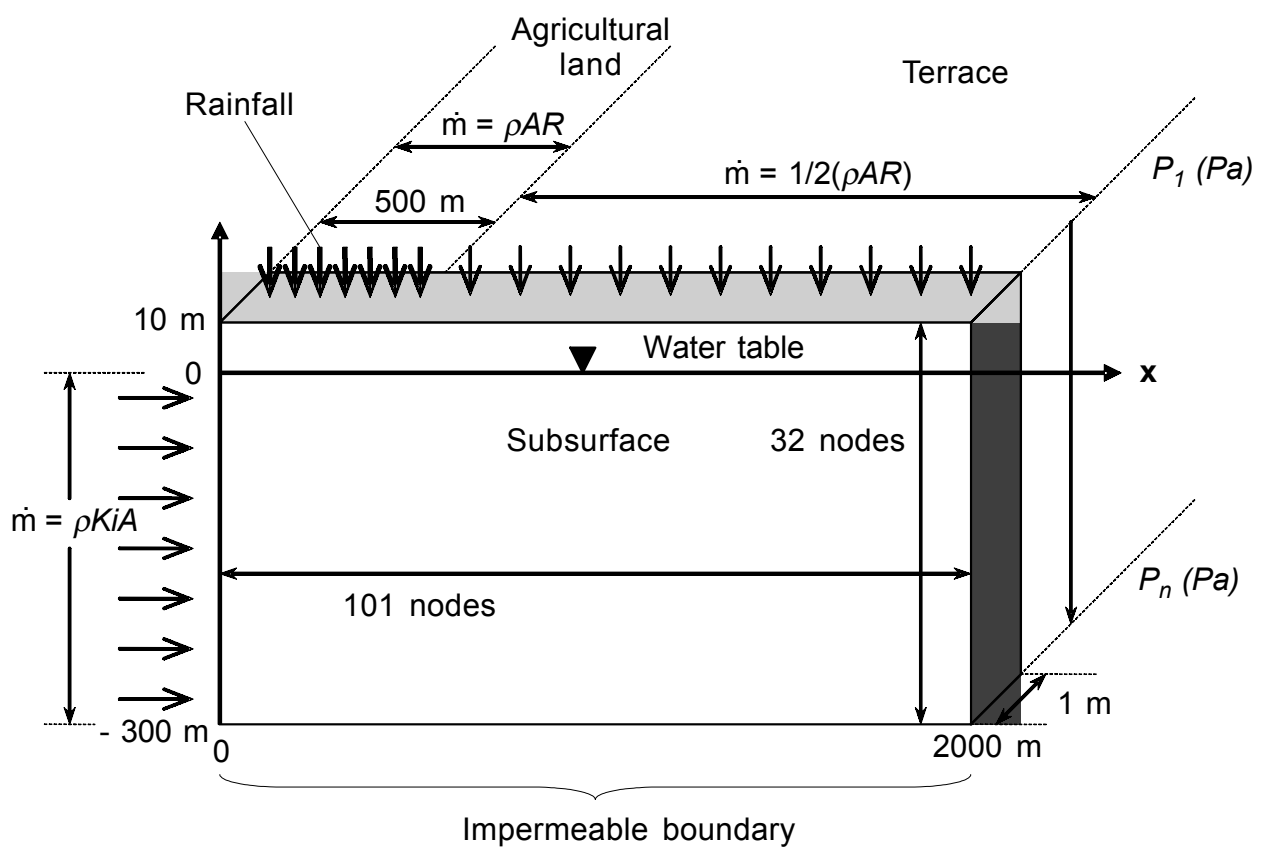

Figure 1 A schematic diagram for hypothetical scenario in Manikganj 
Parameters with average values were fluid compressibility, density of fluid at base concentration, fluid viscosity and recharge. The first three were set at $25^{\circ} \mathrm{C}$, which common range of temperature in Bangladesh between 11 and $35^{\circ} \mathrm{C}$, and recharge was possibly ranged $300-900 \mathrm{~mm} / \mathrm{yr}$, but was set at $600 \mathrm{~mm} / \mathrm{yr}$.

For parameters with the lowest values were fluid diffusivity (literature data limited to $\left.20^{\circ} \mathrm{C}\right)$, solute concentration $(0.1 \mathrm{mg} / \mathrm{L}$, but could possibly ranged $0.1-14 \mathrm{mg} / \mathrm{L})$, left boundary inflow (groundwater gradient of $0.1 \mathrm{~m} / \mathrm{km}$, possibly ranged from 0.1 to $0.5 \mathrm{~m} / \mathrm{km})$ and porosity $(0.25$, ranged $0.25-0.50$ for fine sand).

Finally, heterogeneous, anisotropic, porosity reduction with depths as a result of aquifer compaction, longitudinal and transverse dispersivities, adsorption, abstraction, recharge variation with time and solute decay, were all the parameters not considered at the initial simple modelling work. Subsequently, all these were considered to achieve a more realistic $2 \mathrm{D}$ vertical slide model.

\subsection{RESULTS AND DISCUSSION}

\subsection{Sensitivity Analysis on SUTRA based on Manikganj District}

A quick simulation on the aquifer system with initial input parameters values, and with a time step size of 6,000 seconds with a 1.1 multiplier for time step change cycle after every 9 time steps, showed that time to reached or exceeded the observation depths of $0,40,110$ and $210 \mathrm{~m}$ (vertical distance from surface) were $0.55,15.18,54.15$ and 192.90 years, respectively, with the outer boundary of plume as a reference for indicating time taken by plume in reaching a particular depth. The multiplier rapidly increases the time step size over time and therefore, a few hundred years can be simulated in few minutes and helps in providing a quick initial overview of the solute transport and groundwater flow in the aquifer system.

Throughout the simulation, a slower groundwater flow observed in region approximate to the left side boundary, but as the groundwater flows to the right region, the velocity of water increases, as indicated by the relative tail in Figure 2. This is an expected observation given two types of inflow water combined for a single outflow at the right boundary. As the simulation continue over a period, the plume of solute (assumed to be surface-derived organic carbon) slowly finds its way down to the subsurface, and reaches a maximum depth with a steady state achieved at $225 \mathrm{~m}$, after 238.41 years.

In addition, the simulation has shown that the lowest concentration of solute observed at the outer boundary of the plume. The concentration gradually increases as deeper away from the boundary to the inner part of the plume, and for some distance until which a maximum concentration was reached. Then, it reduced slightly at a shorter further inner distance, before it stabilized at a solute concentration of constant surface recharge water that carried $1.0 \times 10^{-7} \mathrm{~kg}$ solute $/ \mathrm{kg}$ water, for the rests of inner distance. 
SUNNY GOH ENG GIAP

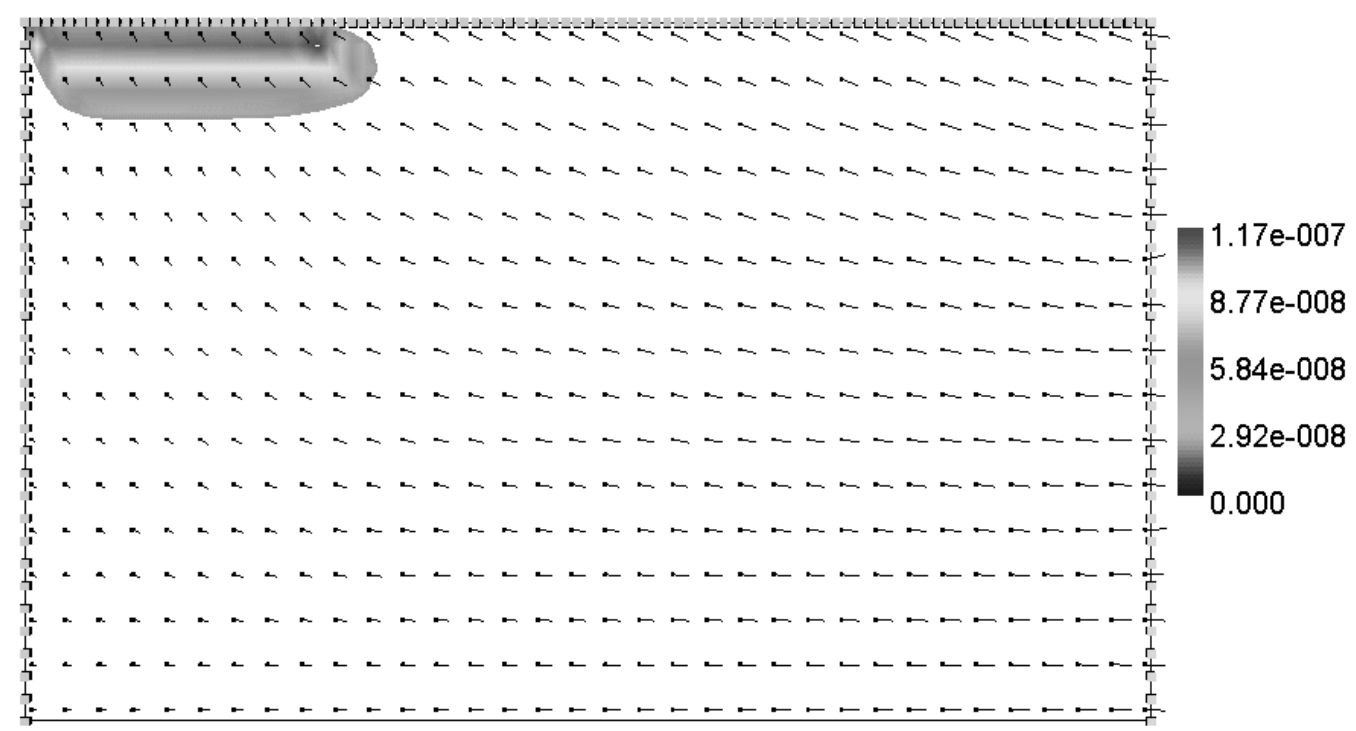

Time $=4.789884 \mathrm{E}+08(640)$

(a)

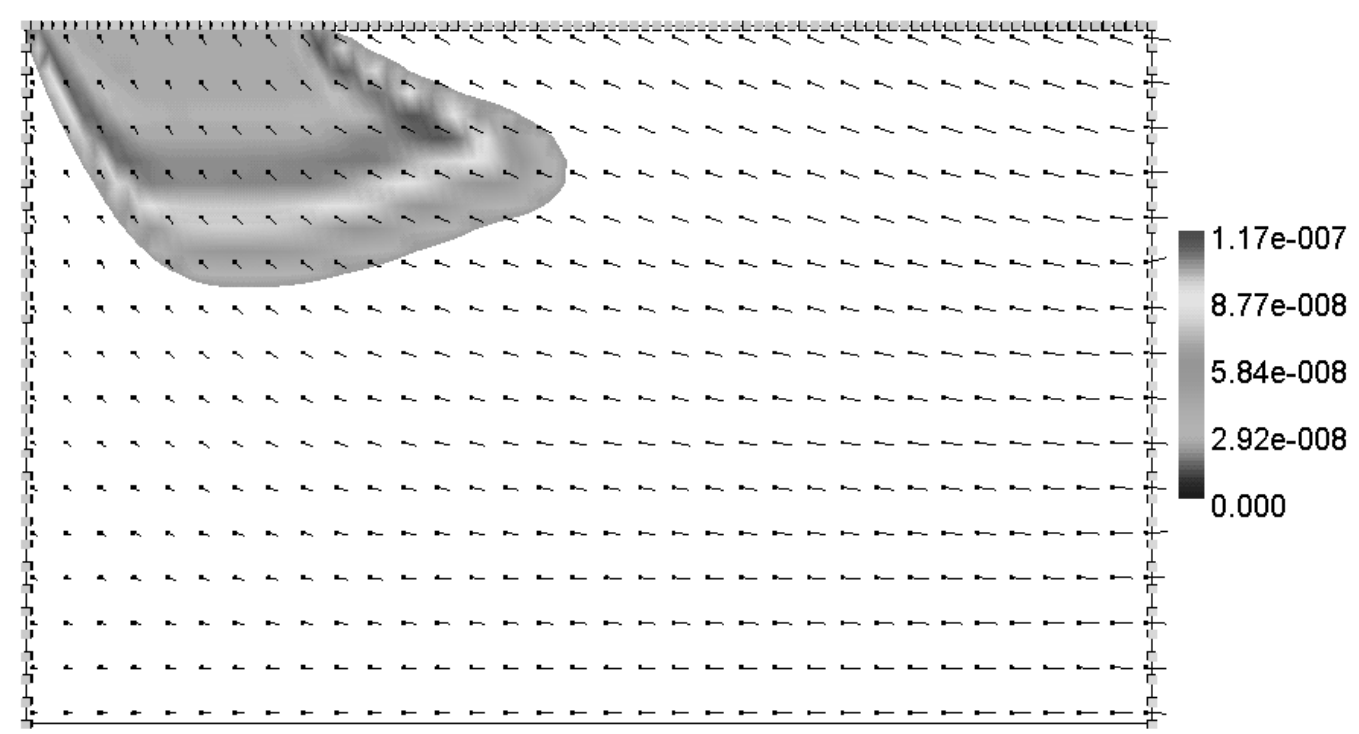

Time $=1.708920 \mathrm{E}+09(760)$

(b) 


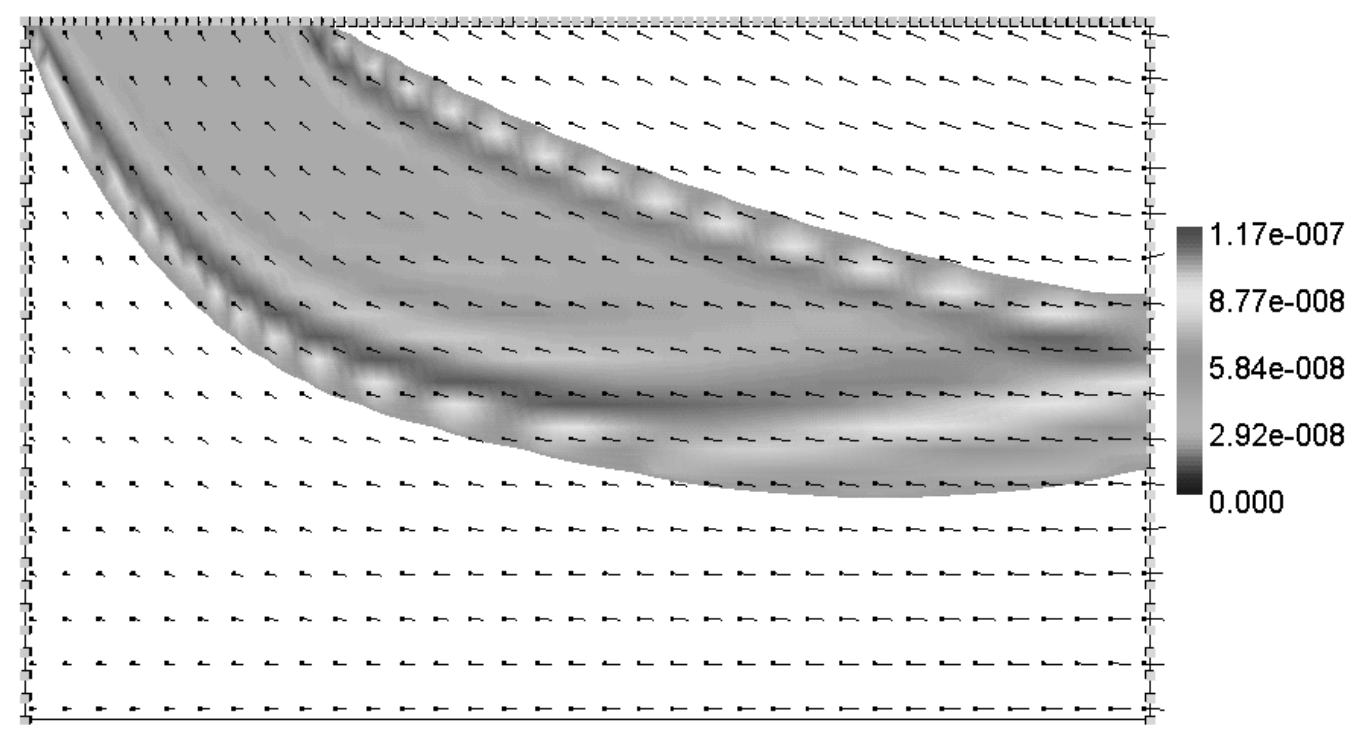

Time $=6.087358 E+09(880)$

(c)

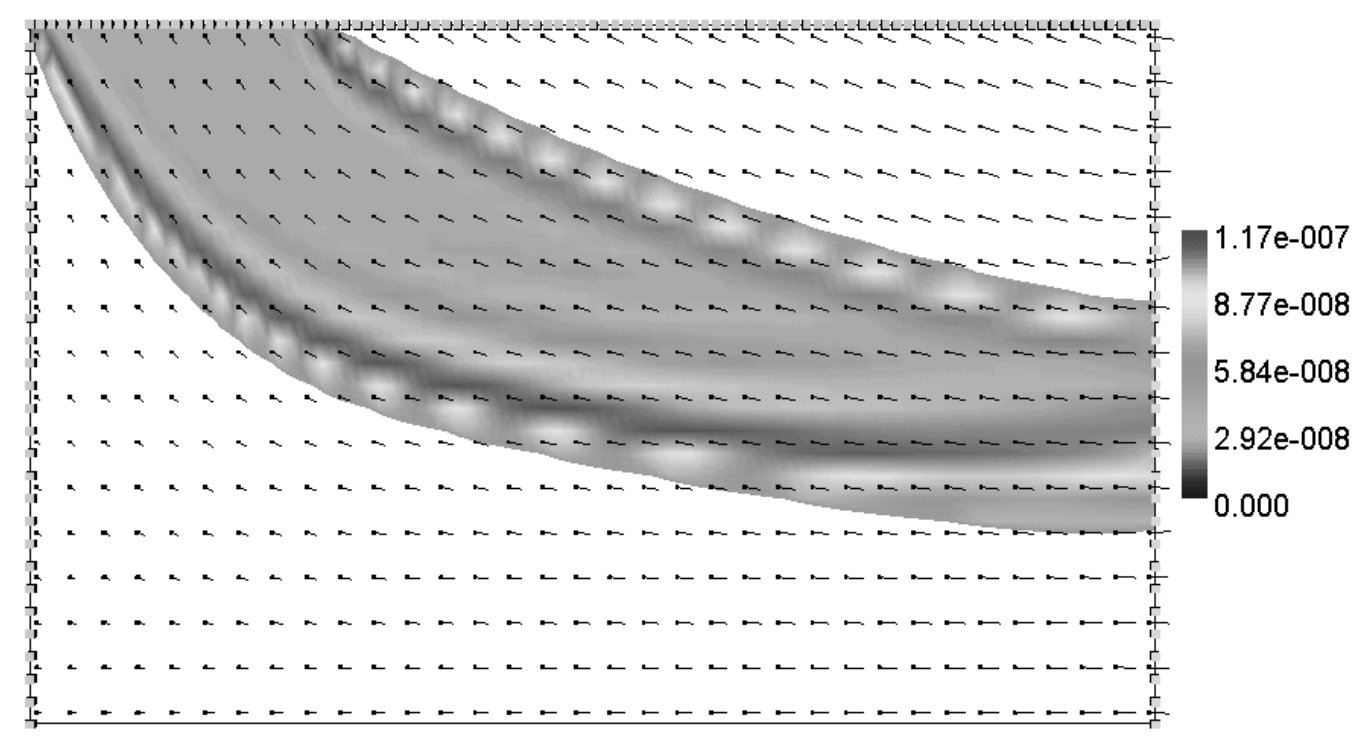

(d)

Figure 2 Solute contour visualization at depths: (a) greater than $40 \mathrm{~m}$ after 15.18 years; (b) greater than $110 \mathrm{~m}$ after 54.15 years; (c) greater than $210 \mathrm{~m}$ after 192.90 years; and (d) maximum, approximately $225 \mathrm{~m}$ after 238.41 years. The legend on the right side of contour graph shows solute concentrations varies from a maximum of $1.16891 \times 10^{-7}$ to a minimum of $2.16891 \times 10^{-8} \mathrm{~kg}$ solute $/ \mathrm{kg}$ water, values above or below these limits will be automatically restricted by these colours. A black small cube distributed within the diagram is called the "base" and its relative tail is showing velocity scalar and vector of groundwater flow 
This phenomenon considered reasonable given a constant solute-free inflow from the left side boundary and an adjacent 1,500 $\mathrm{m}$ surface recharge boundary with solute-free water that responsible for dilution of plume, adding to the advection and diffusion process, though dispersion was not implemented for this simulation.

It is also important to note that this is only a review that based on a quick simulation manipulated with a multiplier for time step change cycle. A more precise simulation requires a selection of smaller time step size (preferably constant) after considering available time for simulation, existing maximum computer capacity and a reasonable consistency for simulated results (means less variation). The following will verify the reasonable time step size for the current simulation and also helps in indicating among all the input parameters required, which of the input parameters are highly and least sensitive based on the tested range of input value.

\subsection{Summary of the Sensitivity Analysis}

From the simulated results for time step size, fluid properties, solid matrix properties and boundary conditions, an inverse magnitude of slope values $\left(|\mathrm{SV}|^{-1}\right)$ for all the input parameters as tabulated in Tables 1 and 2 are categorized under negative and positive relations, respectively. It summarizes the result of magnitude variation of input parameter, either in increasing or decreasing orders, for a unit change of year taken by solute to reach observation depths.

This $|\mathrm{SV}|^{-1}$ value is not suitable for comparison between different parameters because of the base reference point could not be justified. However, by observing the trend of variation on individual input parameter it would still be given useful indication. As tabulated in Tables 1 and 2, all input parameters have shown a decreasing variation on input parameter value as indicated by $|\mathrm{SV}|^{-1}$ as follows: $|\mathrm{SV}|_{0 \mathrm{~m}}^{-1}>|\mathrm{SV}|_{40 \mathrm{~m}}^{-1}>$ $|\mathrm{SV}|_{110 \mathrm{~m}}^{-1}>|\mathrm{SV}|_{210 \mathrm{~m}}^{-1}$, which indicating a smaller change of input parameter value is required to cause one year of difference in reaching deeper observation depth. Thus, a longer simulation time for solute transported into deeper depth of aquifer system will subject to significant variation in time to depth even though a smaller uncertainty of input value is encountered.

In order to consider the extent of possible extreme condition (time) that may be generated by the range of uncertainty of input values for all parameters, the subtraction of upper and lower limits of simulated input values were then divided by $|\mathrm{SV}|^{-1}$ as tabulated in Tables 3 and 4, which is known as the possible variation of time (PVT). The trend of PVT on negative linear relation, by comparing the deepest observation depth, has the following order: Dispersion $<$ Fluid diffusivity $<$ Homogeneous and isotropic $<$ Solute concentration $<$ Porosity reduction rate $<$ Time step size $<$ Constant top boundary recharge. For positive linear relation, PVT as follows: Fluid density at base concentration $<$ Aquifer compressibility $<$ Heterogeneous and Isotropic < Homogeneous and anisotropic $<$ Side boundary inflow $<$ Porosity $<$ Adsorption. These orders imply that a careful selection of input parameter values should be practiced 
Table 1 Apparent negative linear relation of input parameters with time to depth

\begin{tabular}{|c|c|c|c|c|}
\hline \multirow[t]{2}{*}{ Input parameters } & \multicolumn{4}{|c|}{ Inverse magnitude of slope value, $|\mathrm{SV}|^{-1}$} \\
\hline & $0 \mathbf{~ m}$ & $40 \mathrm{~m}$ & $110 \mathrm{~m}$ & $210 \mathrm{~m}$ \\
\hline $\begin{array}{l}\text { Time step size } \\
{[\text { (s)/yr] }}\end{array}$ & $3.33 \mathrm{E}+07$ & $2.00 \mathrm{E}+06$ & $1.00 \mathrm{E}+06$ & $3.33 \mathrm{E}+05$ \\
\hline $\begin{array}{l}\text { Constant top boundary recharge } \\
\text { - actual recharge } \\
{[(\mathrm{mm} / \mathrm{yr}) / \mathrm{yr}]}\end{array}$ & $9.09 \mathrm{E}+02$ & $3.28 \mathrm{E}+01$ & $8.31 \mathrm{E}+00$ & $3.12 \mathrm{E}+00$ \\
\hline $\begin{array}{l}\text { Dispersion } \\
\text { - max. longitudinal dispersivity } \\
{[(\mathrm{m}) / \mathrm{yr}]}\end{array}$ & - & - & - & $5.11 \mathrm{E}-03$ \\
\hline $\begin{array}{l}\text { Hydraulic conductivity } \\
\text { - homogeneous and isotropic } \\
{[(\mathrm{m} / \mathrm{s}) / \mathrm{yr}]}\end{array}$ & - & $7.90 \mathrm{E}-03$ & $5.75 \mathrm{E}-03$ & $3.10 \mathrm{E}-03$ \\
\hline $\begin{array}{l}\text { Porosity } \\
\text { - porosity reduction rate } \\
\text { [(dimensionless)/yr] }\end{array}$ & - & $8.88 \mathrm{E}-04$ & $8.88 \mathrm{E}-05$ & $9.62 \mathrm{E}-06$ \\
\hline $\begin{array}{l}\text { Solute concentration } \\
{[(\mathrm{kg} \text { solute/kg water }) / \mathrm{yr}]}\end{array}$ & - & - & $3.66 \mathrm{E}-05$ & $2.36 \mathrm{E}-06$ \\
\hline $\begin{array}{l}\text { Fluid diffusivity } \\
{\left[\left(\mathrm{m}^{2} / \mathrm{s}\right) / \mathrm{yr}\right]}\end{array}$ & - & - & - & $1.25 \mathrm{E}-09$ \\
\hline
\end{tabular}

Table 2 Apparent positive linear relation of input parameters with time to depth

\begin{tabular}{|c|c|c|c|c|}
\hline \multirow[t]{2}{*}{ Input parameters } & \multicolumn{4}{|c|}{ Inverse magnitude of slope value, $|\mathrm{SV}|^{-1}$} \\
\hline & $\mathbf{0 ~ m}$ & $40 \mathrm{~m}$ & $110 \mathrm{~m}$ & $210 \mathrm{~m}$ \\
\hline $\begin{array}{l}\text { Fluid density at base concentration } \\
{\left[\left(\mathrm{kg} / \mathrm{m}^{3}\right) / \mathrm{yr}\right]} \\
\text { Hydraulic conductivity }\end{array}$ & - & - & $2.92 \mathrm{E}+01$ & $5.78 \mathrm{E}+00$ \\
\hline $\begin{array}{l}\text { - homogeneous and anisotropic } \\
\text { [(dimensionless)/yr] }\end{array}$ & - & $4.83 \mathrm{E}+01$ & $1.81 \mathrm{E}+00$ & $6.27 \mathrm{E}-01$ \\
\hline $\begin{array}{l}\text { Side boundary inflow } \\
\text { - hydraulic gradient } \\
{[(\mathrm{m} / \mathrm{km}) / \mathrm{yr}]}\end{array}$ & - & $3.02 \mathrm{E}-01$ & $1.17 \mathrm{E}-02$ & OS \\
\hline $\begin{array}{l}\text { Hydraulic conductivity } \\
\text { - heterogeneous and isotropic } \\
{[(\mathrm{m}) / \mathrm{yr}]}\end{array}$ & - & $3.39 \mathrm{E}-02$ & $9.60 \mathrm{E}-03$ & $9.98 \mathrm{E}-04$ \\
\hline $\begin{array}{l}\text { Porosity } \\
\text { - no aquifer compaction } \\
\text { [(dimensionless)/yr] }\end{array}$ & $4.56 \mathrm{E}-01$ & $1.75 \mathrm{E}-02$ & $4.93 \mathrm{E}-03$ & $1.31 \mathrm{E}-03$ \\
\hline $\begin{array}{l}\text { Adsorption } \\
\text { - linear distribution coefficient } \\
{\left[\left(\mathrm{m}^{3} / \mathrm{kg} \text { grain }\right) / \mathrm{yr}\right]}\end{array}$ & $2.48 \mathrm{E}-04$ & $9.00 \mathrm{E}-06$ & $2.53 \mathrm{E}-06$ & OS \\
\hline $\begin{array}{l}\text { Aquifer compressibility } \\
{\left[\left(\mathrm{Pa}^{-1}\right) / \mathrm{yr}\right]}\end{array}$ & - & $2.78 \mathrm{E}-07$ & $2.25 \mathrm{E}-07$ & $1.75 \mathrm{E}-07$ \\
\hline
\end{tabular}


Table 3 Calculated possible extreme condition (time) generated by the range of uncertainty of input values for the apparent negative linear relation

\begin{tabular}{lcccc}
\hline Input parameters & \multicolumn{4}{c}{ Possible variation of time, PVT (years) } \\
\cline { 2 - 5 } & $\mathbf{0 ~ m}$ & $\mathbf{4 0 ~} \mathbf{~ m}$ & $\mathbf{1 1 0 ~} \mathbf{~ m}$ & $\mathbf{2 1 0 ~ \mathbf { ~ }}$ \\
\hline $\begin{array}{l}\text { Dispersion } \\
\text { - max. longitudinal dispersivity }\end{array}$ & NA & NA & NA & 0.20 \\
Fluid diffusivity & NA & NA & NA & 0.37 \\
Hydraulic conductivity & NA & 1.25 & 1.72 & 3.18 \\
- homogeneous and isotropic & & & & \\
Solute concentration & NA & NA & 0.38 & 5.89 \\
Porosity - porosity reduction rate & NA & 0.17 & 1.71 & 15.80 \\
Time step size & 0.18 & 2.97 & 5.94 & 17.82 \\
Constant top boundary recharge & 0.66 & 18.30 & 72.24 & 192.12 \\
- actual recharge & & & &
\end{tabular}

"NA" indicates not available for calculation.

Table 4 Calculated possible extreme condition (time) generated by the range of uncertainty of input values for apparent positive linear relation

\begin{tabular}{|c|c|c|c|c|}
\hline \multirow[t]{2}{*}{ Input parameters } & \multicolumn{4}{|c|}{ Possible variation of time, PVT (years) } \\
\hline & $\mathbf{0 ~ m}$ & $40 \mathrm{~m}$ & $110 \mathrm{~m}$ & $210 \mathrm{~m}$ \\
\hline Fluid density at base concentration & NA & NA & 0.19 & 0.95 \\
\hline Aquifer compressibility & NA & 3.56 & 4.39 & 5.65 \\
\hline $\begin{array}{l}\text { Hydraulic conductivity } \\
\text { - heterogeneous and isotropic }\end{array}$ & NA & 0.20 & 0.70 & 6.71 \\
\hline $\begin{array}{l}\text { Hydraulic conductivity } \\
\text { - homogeneous and anisotropic }\end{array}$ & NA & 0.19 & 4.99 & 14.36 \\
\hline $\begin{array}{l}\text { Side boundary inflow } \\
\text { - hydraulic gradient }\end{array}$ & NA & 1.33 & 34.31 & NA \\
\hline Porosity - no aquifer compaction & 0.55 & 14.26 & 50.71 & 190.16 \\
\hline $\begin{array}{l}\text { Adsorption } \\
\text { - linear distribution coefficient }\end{array}$ & 24.23 & 666.54 & 2374.02 & NA \\
\hline
\end{tabular}

"NA" indicates not available for calculation.

when encounter a large PVT of input parameters with range of uncertainty in values. Although decay reaction was not simulated for the current simulation, its contribution would be expected to be in close proximity with the adsorption process.

\subsection{CONCLUSION}

A 2D vertical slide model of transport of surface-derived solutes, based on the drawn down of surface-derived dissolved organic carbon from agricultural area to upper shallow and deeper aquifers, was simulated for one of the typical Manikganj district lithologies. 
The current work was accomplished on a 2D vertical slide model simulations based on a simple hypothetical scenario developed for Manikganj district with simple lithology and assumed typical input parameters values. The understanding of the aquifer system in response to the input parameters that fundamentally governed the system was well investigated through the sensitivity analysis. The results of simulation found that the input parameters can be divided into those with either positive or negative linear relation with the time taken for surface-derived solutes to be transported to typical depths of groundwater abstraction. A gradual increasing in complexity of aquifer system was implemented on Manikganj lithology, and an uncertainty in input values can lead to large variation at greater depths. This was expected due to the fact that an accumulation of similar deviation (different in input values) simulated for over a period of hundred years before surface-derived solutes reaching observation depth, as deeper depth indicates longer simulation time.

The current work can be extended to consider the upper (maximum time) and lower (minimum time) conditions by managing the uncertainty of input values and the introduction of STW and DTW abstractions.

\section{ACKNOWLEDGEMENTS}

The author would like to express his thanks to Dr. David A. Polya and to Dr. William Pao for their supervision, and notably, their professional guidance and advice throughout the work.

\section{REFERENCES}

[1] Charlet, L., and D. A. Polya. 2006. Arsenic in Shallow, Reducing Groundwaters in Southern Asia: An Environmental Health Disaster. Elements. 2: 91-96.

[2] Rowland, H. A. L., D. A. Polya, J. R. Lloyd, and R. D. Pancost. 2006. Characterisation of Organic Matter in a Shallow, Reducing, Arsenic-rich Aquifer, West Bengal. Organic Geochemistry. 37: 1101-1114.

[3] Harvey, C. F., C. H. Swartz, A. B. M. Badruzzaman, N. Keon-Blute, W. Yu, M. A. Ali, J.Jay, R. Beckie, V. Niedan, D. Brabander, P. M. Oates, K. N. Ashfaque, S. Islam, H. F. Hemond, and M. F. Ahmed. 2002. Arsenic Mobility and Groundwater Extraction in Bangladesh. Science. 298: 1602-1606.

[4] Klump, S, R. Kipfer, O. A. Cirpka, C. F. Harvey, M. S. Brennwald, A. B. M. Badruzzaman, S. J. Hug, and D. M. Imboden. 2006. Groundwater Dynamics and Arsenic Mobilization in Bangladesh Assessed Using Noble Gases and Tritium. Environmental Science and Technology. 40: 243-250.

[5] Goh, E. G. 2007. Modelling Impact of Groundwater Flow and Solute Transport on Influx of Surface Derived Organics into Arsenic-Bearing Aquifers in Manikganj District, Bangladesh. MSc. Thesis. The University of Manchester.

[6] Voss, C. I., and A. M. Provost. 2003. SUTRA: A Model for Saturated-Unsaturated, Variable-Density GroundWater Flow with Solute or Energy Transport. USGS. Water Resources Investigations Report 02-4231: $1-260$. 